\title{
Does vitamin D deficiency contribute to post-burn bone loss?
}

\section{[version 1; peer review: 2 approved, 1 approved with}

\section{reservations]}

\section{Gordon L Klein}

Department of Orthopaedic Surgery and Rehabilitation and Shriners Burns Hospital, University of Texas Medical Branch at Galveston, Galveston, 77555 TX, USA

V1 First published: 28 Nov 2012, 1:57

https://doi.org/10.12688/f1000research.1-57.v1

Latest published: 28 Nov 2012, 1:57

https://doi.org/10.12688/f1000research.1-57.v1

\begin{abstract}
Burn injury results in the acute loss of bone as well as the development of progressive vitamin $D$ deficiency. Bone loss occurs acutely due to resorption, which is then followed by apoptosis of osteoblasts preventing repair of the bone loss. The acute resorption is due to a combination of the inflammatory response and the stress response to the burn injury. The resultant production of inflammatory cytokines and endogenous glucocorticoids initially stimulate the osteoblasts to produce RANK ligand, which stimulates marrow stem cell differentiation into osteoclasts. As the stress response persists for approximately one year post-burn the glucocorticoids produced by the body will cause osteoblast apoptosis and adynamic bone, impairing the ability of bone to recover its resorptive losses. The vitamin $D$ deficiency is due to the failure to supplement the diet of burn patients with vitamin $D$ on discharge from hospital and to failure of the skin to make normal quantities of vitamin $D$ on sunlight exposure. Because the bone resorption can be prevented by the acute administration of bisphosphonates it is unlikely that vitamin $D$ deficiency is responsible for the early-onset bone loss following burns. However, because a deficit in trabecular bone remains for at least two years post-burn, it is possible that vitamin $D$ deficiency prevents the recovery of trabecular bone density over the long term.
\end{abstract}

\section{Open Peer Review \\ Approval Status $\checkmark$ \\ 12 \\ 23 \\ version 1 \\ $?$ \\ 28 Nov 2012 \\ 1. Dominique Garrel, Hotel Dieu de CHUM \\ Hospital, Montreal, Canada \\ 2. Daniel Bikle, University of California/VAMC, \\ San Francisco, CA, USA \\ 3. Jon Tobias, Bristol Royal Infirmary, Bristol, \\ UK}

Any reports and responses or comments on the article can be found at the end of the article. 
Corresponding author: Gordon L Klein (gordonklein@ymail.com)

Competing interests: The author has served on the Bone Toxicity Advisory Board for Novartis Pharmaceuticals, August 2012.

Grant information: This work was supported in part by grants from the Shriners Hospitals for Children and by the National Institutes of Health 1 P50 GM60338.

The funders had no role in study design, data collection and analysis, decision to publish, or preparation of the manuscript.

Copyright: ๑ 2012 Klein GL. This is an open access article distributed under the terms of the Creative Commons Attribution License, which permits unrestricted use, distribution, and reproduction in any medium, provided the original work is properly cited. Data associated with the article are available under the terms of the Creative Commons Zero "No rights reserved" data waiver (CC0 1.0 Public domain dedication).

How to cite this article: Klein GL. Does vitamin D deficiency contribute to post-burn bone loss? [version 1; peer review: 2 approved, 1 approved with reservations] F1000Research 2012, 1:57 https://doi.org/10.12688/f1000research.1-57.v1

First published: 28 Nov 2012, 1:57 https://doi.org/10.12688/f1000research.1-57.v1 


\section{Commentary}

Children who have been severely burned develop a progressive vitamin $\mathrm{D}$ deficiency ${ }^{1}$ as characterized by low circulating levels of 25-hydroxyvitamin D (25(OH)D) between $14^{2}$ and 24 months post-burn with normal circulating levels of 1,25-dihydroxyvitamin $\mathrm{D}\left(1,25(\mathrm{OH})_{2} \mathrm{D}\right)$. Unlike rickets there is no compensatory rise in $1,25(\mathrm{OH})_{2} \mathrm{D}$ and this may be due to persistent low serum parathyroid hormone $(\mathrm{PTH})$ concentrations ${ }^{2,3}$. The hypoparathyroidism is likely due to a persistent post-burn up-regulation of the parathyroid calcium sensing receptor ${ }^{3,4}$. By 7 years post-burn, there is a continued reduction in serum levels of $25(\mathrm{OH}) \mathrm{D}$ in all patients but now there is also a reduction in circulating concentrations of $1,25(\mathrm{OH})_{2} \mathrm{D}^{1}$.

There are at least two reasons for this progressive deficiency. The first explanation is that burn patients are not routinely given vitamin D supplements following hospital discharge ${ }^{1}$ and even if they are given a standard amount of vitamin D supplementation, i.e. 400 international units per day, for six months post-burn, serum levels of $25(\mathrm{OH}) \mathrm{D}$ are found to be in the "insufficient" range, approximately $20 \mathrm{ng} / \mathrm{ml}^{5}$. Therefore, the proper dose of vitamin D to administer to these children is unknown. The second explanation is that following burn injury, not only the burn scar tissue but also the adjacent normal-appearing skin cannot convert normal quantities of the precursor 7-dehydrocholesterol (7DHC) to vitamin $\mathrm{D}_{3}$ when subjected to UVB irradiation ${ }^{2}$. Moreover, the epidermal cells both in burn scar tissue and in adjacent normal-appearing skin contain subnormal quantities of 7DHC suggesting abnormalities in cholesterol biosynthesis in skin following burn injury ${ }^{2}$.

Bone loss following burn injury can be attributed to least two non-specific adaptive responses: the inflammatory response and the stress response. Both occur as a result of the destruction of skin, which is an important barrier to infection. The inflammatory response involves significant elevations of circulating cytokines, especially interleukin (IL)- $1 \beta$ and IL- $6{ }^{6}$. The stress response is characterized by a $3-8$-fold rise in endogenous glucocorticoid production as measured by urine free cortisol excretion ${ }^{6,7}$. Acutely, both processes stimulate osteoblast production of the ligand of the receptor activator of NFKB (RANKL), which then stimulates marrow stem cell differentiation into osteoclasts and results in increased bone resorption. The success of acute intravenous administration of bisphosphonates either as a single or once-repeated dose in preventing the bone $\operatorname{loss}^{8}$ is evidence that this is the case. Because the stress response is sustained for as long as one year post-burn, persistence of the elevated endogenous production of glucocorticoids leads to osteoblast and likely osteocyte apoptosis and reduction of marrow stromal cell differentiation into osteoblasts ${ }^{7}$. Thus the now adynamic bone cannot recover the deficit caused by the acute resorption. It is only after the stress response has dissipated after about one year post-burn, that remodeling resumes 9 .

Because the intravenous administration of bisphosphonates prevents the acute bone loss entirely ${ }^{8}$ for up to two years ${ }^{9}$, it is highly unlikely that the documented vitamin D deficiency plays a role in the immediate post-burn bone loss. Moreover, we have also shown that, at least acutely, there are low circulating levels of both vitamin $\mathrm{D}$ binding protein and albumin ${ }^{10}$, with albumin recovering by 6 months post-burn ${ }^{5}$. Therefore, whether there is true vitamin D deficiency during the first six months post-burn is difficult to determine. Nevertheless, what we do see in these burn patients is that by two years post-burn, cortical bone deficits, as measured by total body bone mineral content, in those not receiving acute bisphosphonate therapy recover to the level of those who did receive bisphosphosphonates ${ }^{9}$ while the deficit in trabecular bone, as measured by lumbar spine bone density, persisted ${ }^{9,11}$.

A recent report by Zhou et al. ${ }^{12}$ has shown that in adult human marrow stromal cell culture, the clinical conditions under which the bone biopsies were obtained influenced the ability of the stromal cells to differentiate into osteoblasts in response to $1,25(\mathrm{OH})_{2} \mathrm{D}$. In particular it was noted that vitamin D deficiency impaired this differentiation. This finding raises the possibility that progressive vitamin $\mathrm{D}$ deficiency as experienced by children post-burn may explain the persistence of their trabecular bone deficit, although why vitamin $\mathrm{D}$ deficiency would uniquely affect trabecular bone is not at all clear. Perhaps future studies looking at the differential effects of vitamin $\mathrm{D}$ on cortical and trabecular bone might determine whether this hypothesis is viable.

\section{Competing interests}

The author has served on the Bone Toxicity Advisory Board for Novartis Pharmaceuticals, August 2012.

\section{Grant information}

This work was supported in part by grants from the Shriners Hospitals for Children and by the National Institutes of Health 1P50 GM60338.

The funders had no role in study design, data collection and analysis, decision to publish, or preparation of the manuscript.
1. Klein GL, Langman $C B$, Herndon $D N$ : Vitamin $D$ depletion following burn injury in children: a possible factor in post-burn osteopenia. $J$ Trauma. 2002; 52(2): 346-50.

PubMed Abstract

2. Klein GL, Chen TC, Holick MF, et al:: Synthesis of vitamin D in skin after burns. Lancet. 2004; 363(9405): 291-2. PubMed Abstract | Publisher Full Text
3. Klein GL, Nicolai M, Langman CB, et al.: Dysregulation of calcium homeostasis after severe burn injury in children: possible role of magnesium depletion. J Pediatr. 1997; 131(2): 246-51. PubMed Abstract

4. Murphey ED, Chattopadhyay N, Bai M, et al:: Up-regulation of the parathyroid calcium-sensing receptor after burn injury in sheep: a potential contributory factor to post-burn hypocalcemia. Crit Care Med. 2000; 28(12): 3885-90. PubMed Abstract 
5. Klein GL, Herndon DN, Chen TC, et al.: Standard vitamin D supplementation does not improve vitamin D insufficiency after burns. J Bone Miner Metab. 2009; 27(4): 502-6.

PubMed Abstract | Publisher Full Text

6. Klein GL, Herndon DN, Goodman WG, et al:: Histomorphometric and biochemical characterization of bone following acute severe burns in children. Bone. 1995; 17(5): 455-60.

PubMed Abstract

7. Klein GL, Bi LX, Sherrard DJ, et al.: Evidence supporting a role of glucocorticoids in the short-term bone loss in burned children. Osteoporos Int 2004; 15(6): 468-74.

PubMed Abstract | Publisher Full Text

8. Klein GL, Wimalawansa SJ, Kulkarni G, et al:: The efficacy of acute administration of pamidronate on the conservation of bone mass following severe burn injury in children: a double-blind, randomized, controlled study. Osteoporos Int. 2005; 16(6): 631-5.

PubMed Abstract | Publisher Full Text
9. Przkora R, Herndon DN, Sherrard DJ, et al.: Pamidronate preserves bone mass for at least 2 years following acute administration for pediatric burn injury. Bone. 2007; 41(2): 297-302.

PubMed Abstract | Publisher Full Text | Free Full Text

10. Klein GL, Herndon DN, Rutan TC, et al:: Bone disease in burn patients. J Bone Miner Res. 1993; 8(3): 337-45.

PubMed Abstract | Publisher Full Text

11. Klein GL, Herndon DN, Langman $\mathrm{CB}$, et al.: Long-term reduction in bone mass after severe burn injury in children. $J$ Pediatr. 1995; 126(2): 252-6.

PubMed Abstract

12. Zhou S, Glowacki J, Kim SW, et al.: Clinical characteristics influence in vitro action of 1,25-dihydroxyvitamin $\mathrm{D}(3)$ in human marrow stromal cells. J Bone Miner Res. 2012; 27(9): 1992-2000.

PubMed Abstract | Publisher Full Text | Free Full Text 


\title{
Open Peer Review
}

\section{Current Peer Review Status:}

\section{Version 1}

Reviewer Report 22 January 2013

https://doi.org/10.5256/f1000research.234.r384

(C) 2013 Tobias J. This is an open access peer review report distributed under the terms of the Creative Commons Attribution License, which permits unrestricted use, distribution, and reproduction in any medium, provided the original work is properly cited.

\author{
Jon Tobias \\ Musculoskeletal Research Unit, Bristol Royal Infirmary, Bristol, UK \\ My reservations are as follows:
}

1. Since children are not routinely supplemented with vitamin $D$, the lack of vitamin $D$ supplementation in burn victims is not in itself an explanation for their low vitamin D levels.

2. The assertion that elevated endogenous glucocorticoids contribute to bone loss in this context, through inhibition of osteoblast survival and generation, is somewhat over-stated. Although adverse effects of glucocorticoids on osteoblast function are well described, the literature mainly applies to pharmacological doses of glucocorticoid. The evidence cited here, concerning possible adverse effects of endogenous glucocorticoids, relates to a small observational study which provides weak circumstantial evidence at best.

Competing Interests: No competing interests were disclosed.

\section{I confirm that I have read this submission and believe that I have an appropriate level of expertise to confirm that it is of an acceptable scientific standard, however I have significant reservations, as outlined above.}

\section{Author Response 30 Nov 2012}

Gordon Klein, Department of Orthopaedic Surgery and Rehabilitation and Shriners Burns Hospital, Unievrsity of Texas, Medical Branch, USA

The comments from Dr Tobias are greatly appreciated. If I did not make it clear in the commentary I listed two contributory factors to post-burn vitamin D deficiency. The failure to supplement is not of itself a causative factor, I agree, but the fact that the skin cannot make vitamin D normally on exposure to UVB radiation coupled with the lack of routine supplementation means that the burn victims have no way to compensate for the skin's 
failure to normally synthesize vitamin D3 from its precursor.

With regard to the comment on endogenous glucocorticoids clearly $\mathrm{Dr}$ Tobias is correct in stating that the literature on glucocorticoid-induced osteoporosis relates to the exogenous administration of glucocorticoids. the studies that I have cited, albeit they are my own, demonstrate that the body produces large quantities of endogenous glucocorticoids in response to stress, coupled with lack of surface osteoblasts and a reduction in markers of osteoblast differentiation in marrow stromal cells taken from the burn victims as compared to unburned controls. The point to be emphasized, I believe, is that currently there is no way to equate the quantity of endogenous glucocorticoids produced in response to stress with the dosage of glucocorticoids given as therapy. In the absence of work corroborating our observations I raise the issue of similar effects of endogenous and exogenous glucocorticoids in order to increase awareness that in the case of burns at least the classic manifestations of glucocorticoid induced osteoporosis also exist in children who did not receive exogenous glucocorticoids, I would certainly agree that more studies in this area and in different conditions in which a patient is subject to stress would help clarify the situation, but I would not dismiss the argument for lack of evidence.

Competing Interests: No competing interests were disclosed.

Reviewer Report 30 November 2012

https://doi.org/10.5256/f1000research.234.r383

(C) 2012 Bikle D. This is an open access peer review report distributed under the terms of the Creative Commons Attribution License, which permits unrestricted use, distribution, and reproduction in any medium, provided the original work is properly cited.

\section{Daniel Bikle}

Department of Medicine and Dermatology, University of California/VAMC, San Francisco, CA, USA

Competing Interests: No competing interests were disclosed.

I confirm that I have read this submission and believe that I have an appropriate level of expertise to confirm that it is of an acceptable scientific standard.

Reviewer Report 28 November 2012

https://doi.org/10.5256/f1000research.234.r382

(C) 2012 Garrel D. This is an open access peer review report distributed under the terms of the Creative Commons Attribution License, which permits unrestricted use, distribution, and reproduction in any medium, provided the original work is properly cited. 


\section{Dominique Garrel}

Endocrinology Department, Hotel Dieu de CHUM Hospital, Montreal, Canada

Competing Interests: No competing interests were disclosed.

I confirm that I have read this submission and believe that I have an appropriate level of expertise to confirm that it is of an acceptable scientific standard.

The benefits of publishing with F1000Research:

- Your article is published within days, with no editorial bias

- You can publish traditional articles, null/negative results, case reports, data notes and more

- The peer review process is transparent and collaborative

- Your article is indexed in PubMed after passing peer review

- Dedicated customer support at every stage

For pre-submission enquiries, contact research@f1000.com 